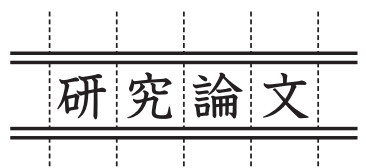

\title{
旋回流を伴う希薄予混合燃焼における火炎伝播挙動に及ぼす流れ場の影響 \\ The Effect of Flow Field on Flame Propagation Behavior in Lean Premixed Combustion with Swirling Flow
}

\author{
市川 雄 一*・小宮山正治**・小山敦 ${ }^{*}$ * \\ Yuichi ICHIKAWA, Masaharu KOMIYAMA and Atsushi KOYAMA
}

(Received September 25. 2015)

\begin{abstract}
Lean premixed combustion is one of the most promising techniques to reduce nitrogen oxide $\left(\mathrm{NO}_{\mathrm{x}}\right)$ emissions. However, lean premixed combustors have a narrow stable combustion range compared with diffusion combustors and have a risk of flashback. Flashback into the fuel nozzle causes serious damage to combustors. So, in this study we aim to clarify the relationship between the flame behavior and the flow fields in the premixed combustors with swirling flow by applying high-speed stereo particle image velocimetry (PIV) measurement. In this measurement, use of olive oil particles as tracer particles permits us to capture not only the flow fields but also the flame behavior. Then, we prepared two experimental conditions on the flow fields which have different swirl intensity; swirl number $S=0.242$ and 0.633 . These different conditions on swirl intensity can be realized by using a variable swirler whose vane angle is changeable. This variable swirler makes it possible to independently change of swirl intensity. In $S=0.633$, it is clarified that both axial velocity and circumferential velocity of premixed gas upstream the flame tip have relationships with flame propagation velocity. In short, the local strengthening of swirl intensity in the vicinity of flame tip influences the flame propagation velocity when swirl intensity is strong. On the other hand, it is found that flame propagation velocity has relation to only axial velocity of premixed gas under $S=0.242$. Briefly, the change in eddy structure of swirling flow influences the flame propagation velocity when swirl intensity is weak.
\end{abstract}

Key Words: Gas Turbine, Lean Premixed Combustion, Flashback, High-speed Stereo PIV

\section{1. 緒 言}

2011 年に発生した原子力発電所に打ける事故以降、火力 発電が果たす役割が大きくなっているため、これまで高効 率な発電に大きく貢献してきた産業用ガスタービンに注目 が集まっている。一方、近年では二酸化炭素など温室効果 ガスの増加が原因と考えられている地球温暖化やそれに伴 う異常気象が大きな問題となっているため、ガスタービン には更なる高効率化が求められている。そのため、熱効率 向上の有効な手段として、燃料を燃焼させる温度を上昇さ せる傾向にあるが、それに伴って、光化学スモッグや酸性 雨の原因となる窒素酸化物 (NOx) の排出量は増加するため 問題となる。そこで、産業用ガスタービンの一部では、空 気過多の状態で燃料と空気を混合させた後、燃焼させる希 薄予混合燃焼が採用されている。予混合燃焼では、従来用 いられてきた拡散燃焼に比べて、燃料と空気の混合が不十 分なために生じる局所的高温部を低減することができるた
め、NOx 生成を抑制する効果がある。しかし、予混合燃焼 は火炎の安定範囲が狭く、逆火や振動燃焼などのデメリッ トがある。本研究で中心に扱う逆火とは、火炎が燃料や酸 化剤の供給方向に逆らって上流側へ伝播する現象であり、 燃料・酸化剤供給部などを焼損させ機器の信頼性低下にも 繋がる。

そのため、工業的には火炎の伝播限界が重要な要素の 1 つであり、火炎伝播の限界に関する報告 ${ }^{1), 2}$ がいくつかあ る。それに加えて、逆火発生のメカニズム解明のため基礎 的な現象として詳細に解析を行っている研究報告 ${ }^{3), 4}$ もあ る。また、逆火は火炎伝播の形態によって一般的に、(1) 壁 面付近の境界層に抢ける火炎伝播 ${ }^{1} 、(2)$ 乱流燃焼速度の増 加による火炎伝播、(3) 燃焼の不安定性に起因する火炎伝 播、(4) 渦崩壊による火炎伝播に分けられる。特に、ガスター ビン燃焼器に扔いて見られる旋回流を伴う流れ場での逆火 では、渦崩壊による火炎伝播に起因するものが主要なもの として捉えられている。従来までの研究としては、円管内

* 大阪大学大学院工学研究科 機械工学専攻（５ 565-0871 大阪府吹田市山田丘 2-1）

Department of Mechanical Engineering, Graduate School of Engneering, Osaka University (2-1 Yamada0ka, Suita, Osaka, 565-0871 Japan) **岐阜大学工学部 機械工学科（～201-1193 岐阜県岐阜市柳戸 1-1）

Department of Mechanical Engineering, Faculty of Engineering, Gifu University (1-1 Yanagido, Gifu, Gifu, 201-1193 Japan) 
で誘起される逆火に対して、粒子画像流速測定法 (PIV) と OH-LIF の同時計測を行い、流れ場の可視化と火炎面の位置 を明らかにし、周囲の再循環領域と火炎面の相互関係を実 験的に検証した結果、再循環領域の先端における流れ場の 変化が逆火と密接に関連していることが報告されている5)。 同様に PIV と OH-LIF の同時計測を渦心の歳差運動 (PVC) を伴う流れ場に適応し、PVCの周期に合わせて変化する 流速と $\mathrm{OH}$ 分布のパターンが明らかにされている6。また、 旋回を伴う燃焼器における流れを実験的に分析し、一定燃 料流量で空気流量を増加させた場合のノズル出口に形成さ れる円錐形状の予混合火炎の挙動を観察した報告 ${ }^{7)}$ もる。 これらは、旋回流を伴う流れ場における逆火に注目したが、 その強さが流れ場や火炎形状 (本研究では火炎が存在する 領域を指す）そして圧力変動に与える影響も報告されてい る $^{8)}$ 。

しかし、旋回流中における火炎の逆火は、渦崩壊に伴う 非定常な流れ場と火炎伝播が相互干渉する複雑な現象であ るため、そのメカニズムは未だ解明されていない部分が多 い。そこで、筆者らは過去に予混合燃焼器を模擬したガラ ス円管などから成る実験用燃焼器で撮影カメラ 1 台による 時系列 PIV 計測を行い、流れ場分布と火炎形状を同時に取 得することを行った ${ }^{9}$ 。そこして、火炎先端 (本研究では最 も上流側に存在する火炎面を指す）の周りに存在する未燃 予混合気の火炎伝播方向流速と火炎の伝播挙動に関する相 互関係について時系列に沿って明らかにした。本報では、 さらに詳細な火炎伝播のメカニズムを解明するため、旋回 流を伴う流れ場における火炎伝播に関して重要な役割を果 たす旋回流の周方向速度と火炎伝播の相互関係を明らかに することを目的とした。そのため、時間的に一定に固定し た旋回強さ 2 種類の流れ場に対して、2 台の高速度カメラ を用いた時系列ステレオ PIV 計測を行い、火炎先端周辺に 存在する未燃予混合気の流速に関して、旋回流の周方向を 含む測定平面内 3 方向成分と、火炎伝播挙動の両者を同時 にかつ高い時間分解能で連続的に取得した。

\section{2. 実験装置 - 方法}

実際のガスタービン燃焼器は複数の燃焼器から成り、本 研究では予混合燃焼が行われている燃焼器の 1 つを模擬し た実験用燃焼器（Fig.1）を対象に実験を行った。燃料につ いては、多くのガスタービンで然料として用いられている 天然ガスの主成分であるメタン $\left(\mathrm{CH}_{4}\right)$ を用いた。燃焼器底 部より燃料と空気を別々に取り入れ、燃焼器中心軸にあり 直径 $1 \mathrm{~mm}$ の穴が 18 個空けられた燃料ノズルから燃料を噴 き出し、周囲の空気と混合させ、その混合ガスをスワーラ に通すことにより旋回を与えた。本実験で用いたスワーラ はFig.2で示すように、36枚の羽根から成り立っており、 羽根角度を変更させることによって、旋回流の強さを独立 に変化させることができる仕組みになっている。旋回を与

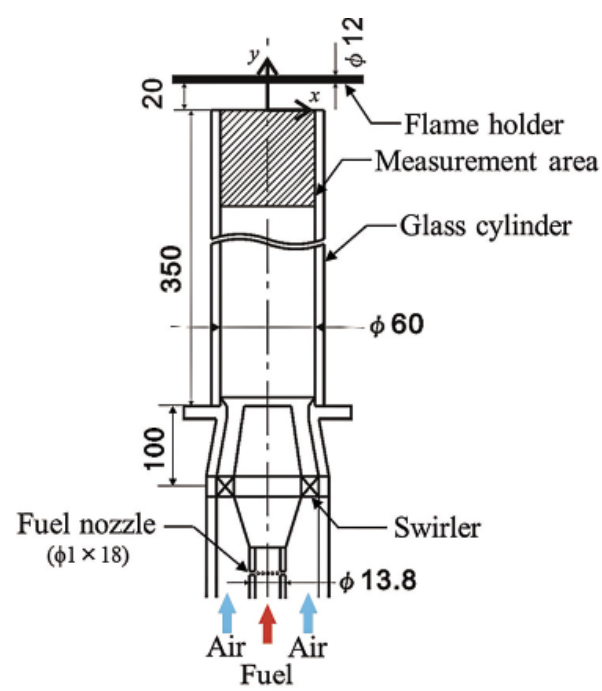

Fig.1 Schematic view of premixed combustor.
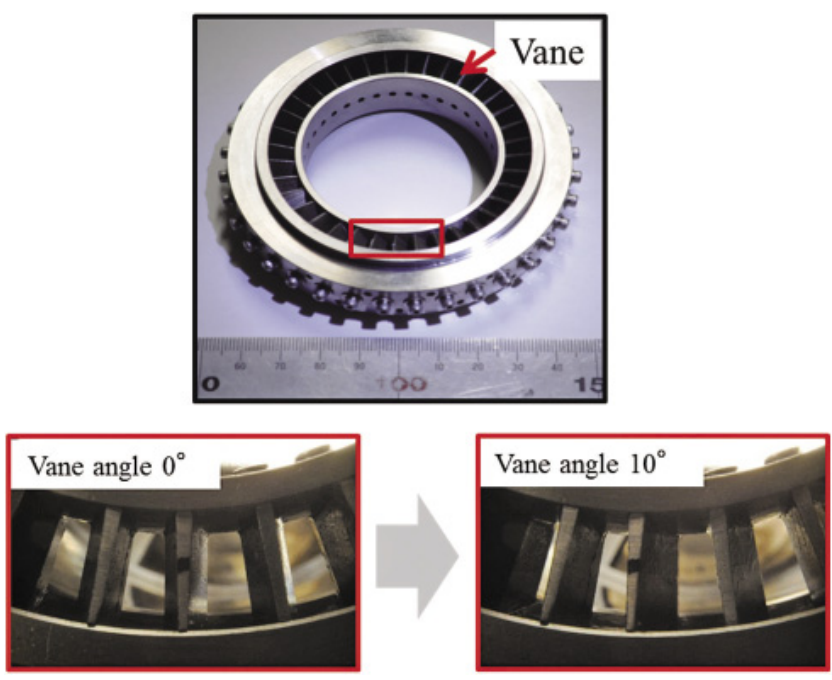

Fig.2 Variable swirler.

えられた混合ガスは、燃焼器の閉鎖空間を模擬したガラス 円筒管（長さ $350 \mathrm{~mm}$ 内径 $60 \mathrm{~mm}$ ）の内部を流れ大気中へ 開放される。ガラス円筒管の材質については、レーザ光を 透過し、円筒管内部の火炎形状と流れ場を可視化できるよ うにするため、透明な合成石英とした。また、ガラス円筒 管上端より $20 \mathrm{~mm}$ 上方に保炎器として直径 $12 \mathrm{~mm}$ のセラ ミック製円柱を設置した。特に、火炎先端の動的挙動と周 囲の未燃予混合気の流れ場を同時に捉えるため、Fig.1の 斜線部が示すガラス管出口付近の領域に対して時系列ステ レオ PIV 計測を導入し、両者の相互関係について考察を行っ た。また、使用する座標系については、ガラス管上端面に おける中心を原点とし、半径方向に $x$ 軸を、ガラス管軸上 方向に $y$ 軸を、紙面垂直方向に $z$ 軸を設定する。 


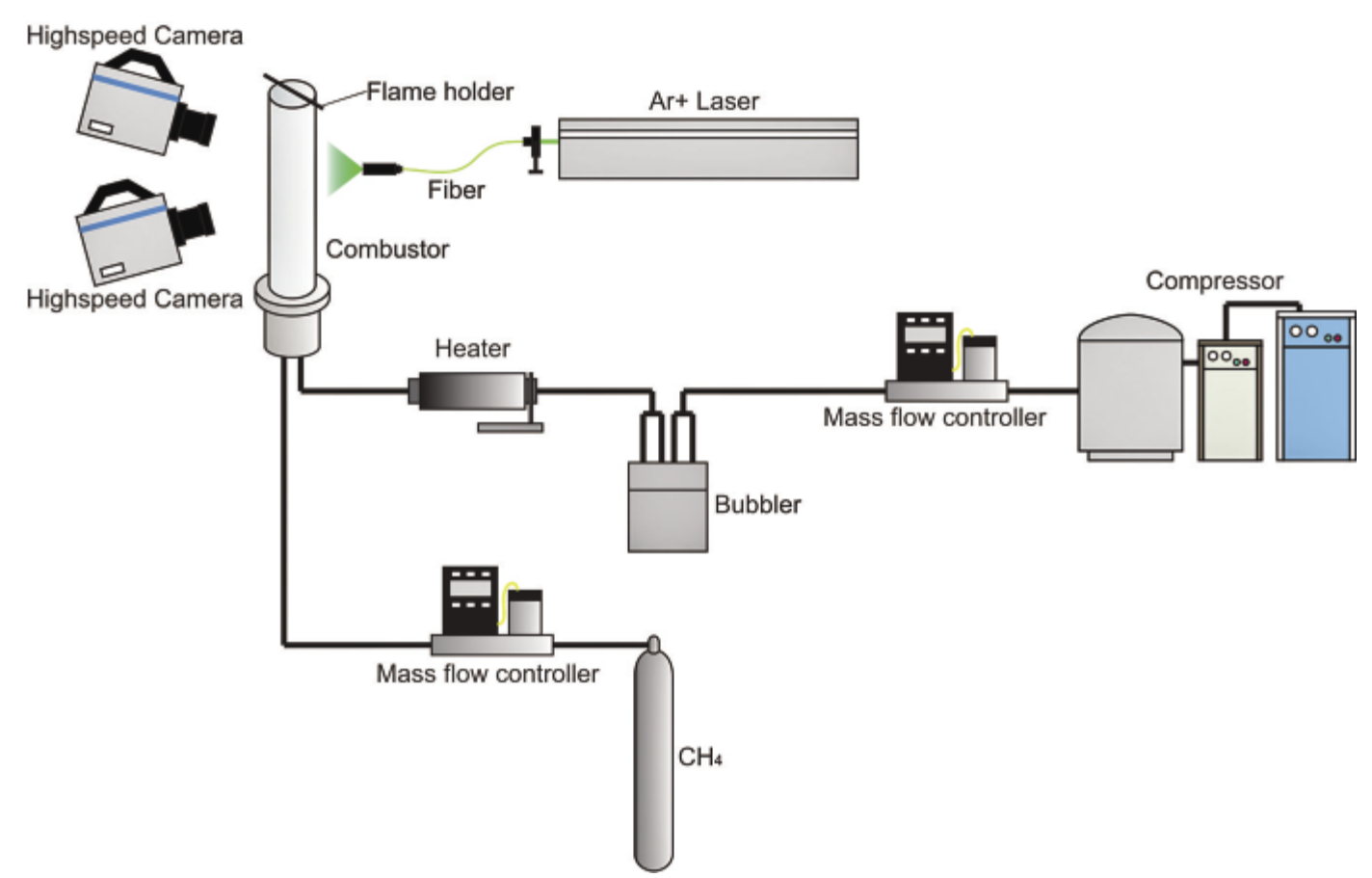

Fig.3 Experimental apparatus for time-series stereo PIV measurement.

次に、Fig.1に示した実験用燃焼器を含む全体的な実験 装置について、その概念図である Fig.3を用いて述べる。 PIV 計測とは、流れ場に混入させたトレーサ粒子がレーザ シート面内を移動する量から面に平行な速度 2 成分を測定 する手法である。本実験では、上記のトレーサ粒子として 直径約 $1 \mu \mathrm{m}$ のオリーブオイル粒子を利用し、Fig.3が示す ように、コンプレッサから供給された空気に混入させ実験 用燃焼器に導いた。トレーサ粒子については、オリーブオ イルが満たされた圧力容器内に空気を供給し、ラスキンノ ズルを通して生成している。また、オリーブオイル粒子は、 可燃性であり火炎中では焼失するため、流れ場と同時に 火炎形状を取得することが可能である。PIV 用の光源には

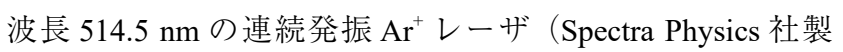
Stabilite2017、定格出力 $6 \mathrm{~W}$ ）を用いた。このレーザ光をファ イバに入射させ、ファイバ出口に取り付けたコリメータに よって厚さ $1 \mathrm{~mm}$ のレーザシートを作成した。このコリメー 夕については、ガラス管からの反射を防ぐため測定範囲に 対して斜め下方から照射するよう設置した。

ここで、本報で用いるステレオ PIV 計測について述べる。 ステレオ PIV 計測とは、上述したカメラ 1 台による通常 の PIV 計測にもう 1 台のカメラを加えることによって、測 定平面に平行な速度べクトル 2 成分に加え、面に垂直な成 分も算出できる。本実験では、時系列ステレオ PIV 計測を 行うにあたり、トレーサ粒子からの散乱光強度を強め、相 対的にガラス管表面における反射の影響を低減するため、 2 台の高速度カメラ（Photoron 社製FASTCAM SA-3 model
120K-M2 $1024 \times 1024$ pixels）をレーザシート前面に互いに $30^{\circ}$ の角度をなす位置に向かい合わせた。さらに、左右斜 め方向から撮影する画像のピントを各カメラで画像全体に わたって合わせるため、カメラの撮像面とレンズ主平面そ してレーザシートの延長線が一点に交わるようにカメラと レンズを設置するシャインフラグ配置を用いた。各カメラ で撮影した粒子画像には歪みが生じる。そのため、写像関 数を用いて生じた画像の歪みを修正した。その修正方法は 以下の通りである。まず初めに、2.5 mm 間隔で水平方向と 垂直方向にそれぞれ点を打った歪み補正用のキャリブレー ション用プレートを用意する。そして、燃焼器を模擬した 円筒管内にこのキャリブレーション用プレート設置し、左 右にシャインフラグ配置した場所から撮影した 2 枚の画像 とプレート正面から撮影した 3 枚の画像を撮影する。Fig.4 は、この 3 枚の画像を示している。正面から撮影した画像 と左右から撮影したそれぞれの画像において、プレート上 の対応する点の位置から写像関数を求める。ここで得た写 像関数を用いて左右から撮影した歪んだ粒子画像を修正す る。左右の画像に再帰的相互相関法を用いて変位べクトル 計測処理を行い、上記の手順で相互相関法を用いることに よって、歪みを排除した 2 次元 2 成分速度べクトルを算出 する。最後に、2 次元 3 成分速度べクトルを、左右それぞ れのカメラで撮影した 2 枚の 2 次元 2 成分速度ベクトルか ら求める。また、曲率半径の小さい円筒管内での PIV では、 円筒面上でのレーザ光の反射とトレーサ粒子像が重なるた め、正しく速度べクトルを算出することが困難となる。そ 


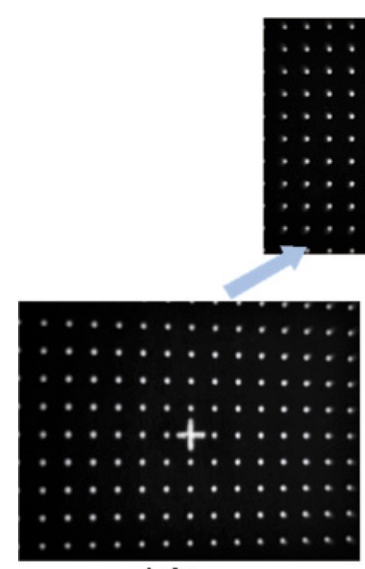

left

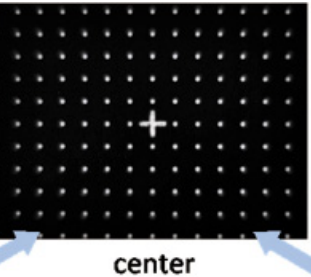

center
Fig.4 Calibration of the distorted images.

こで、本研究では円筒管からの反射の影響を低減するため に、粒子を含んだ未燃予混合気を流さない状態にて石英ガ ラス管にレーザ光を照射させた画像を取得し、トレーサ粒 子画像から反射による光強度を差し引いている。な挔、撮 影に扔ける空間分解能は高速度カメラのピクセル間距離に 相当し約 $0.10 \mathrm{~mm}$ であった。撮影速度については、検出可 能最小速度が空気流量 $Q_{a i r}$ から算出される平均流速 $v_{a v e}$ (本 実験では最小流量を $Q_{a i r}=50 \mathrm{NL} / \mathrm{min}$ としたため、 $v_{a v e}=0.3$ $\mathrm{m} / \mathrm{s}$ ）の 1/10 以下であり、同じく平均流速で動いたトレー サ粒子が厚さ $1 \mathrm{~mm}$ のレーザシートを突き抜けるために必 要な時間の $1 / 10$ 程度になる $2000 \mathrm{frame} / \mathrm{s}$ とした。

実験条件については、旋回強さを数種類用意し、未燃状 態におけるガラス管出口温度を $293 \mathrm{~K}$ 、空気流量 $Q_{a i r}$ を 50

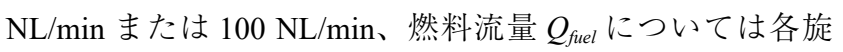
回強さに打いて逆火に至る限界值に設定した。本実験では、 旋回強さを表す指標としてスワール数 $S$ を用い、スワーラ 形状 $\left(R_{i}\right.$ : 内径、 $R_{o}$ : 外径 $)$ と羽根角度 $\alpha$ の幾何的情報か ら式(1)を用いて算出した ${ }^{10)}$ 。

$$
S=\frac{2}{3} \tan \alpha \frac{1-R^{3}}{1-R^{2}}\left(R=R_{i} / R_{o}\right)
$$

\section{3. 結果と考察}

まず、旋回流の旋回強さが逆火の特性に与える影響を明 らかにするため、旋回強さを示すスワール数が異なる旋回 流中に扮いて、逆火限界空気比の測定を行った。逆火限界 空気比の測定方法については、空気流量 $Q_{a i r}$ を 50 または $100 \mathrm{NL} / \mathrm{min}$ に固定したまま、燃料流量 $Q_{\text {fuel }}$ を徐々に増やす ことによって逆火を引き起こし、その時の空気比を逆火限 界空気比とした。本実験に扔ける逆火の定義としては、火 炎全体が保炎器を離れ、戻ることができない時とし、具体 的にはガラス管下端より $10 \mathrm{~mm}$ 上方の位置に至ったとき

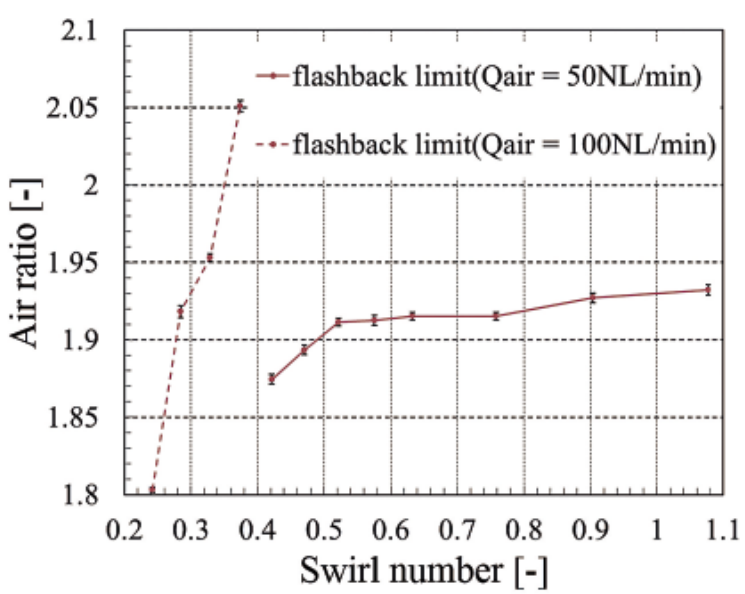

Fig.5 Flashback limit map.

とした。逆火限界空気比の值は、5 回測定した平均值とし、 標準偏差も Fig.5に示す。本実験では、PIV 計測のトレー サ粒子として燃料の一部となるオリーブオイル粒子を空気 に混入させているため、逆火限界空気比に対して、トレー サを混ぜない場合と比較して最大 $2 \%$ 上昇の影響がある。

そして、この Fig.5 で示した各空気流量 $Q_{a i r}$ に扔けるス ワール数 $S$ に対する逆火限界空気比の結果のうち、旋回強 さが大きく異なる 2 条件に対して、燃焼場での時系列ステ レオPIV 計測を行った。検討した条件は、旋回強さが強い 条件 A $\left(Q_{a i r}=50 \mathrm{NL} / \mathrm{min}\right.$ かつ $\left.S=0.633\right)$ と、旋回強さが弱 い条件 B ( $Q_{a i r}=100 \mathrm{NL} / \mathrm{min}$ かつ $\left.S=0.242\right)$ である。燃料 流量については、各実験条件に打ける逆火限界空気比にな るように設定した。この逆火限界空気比に設定した各条件 では、火炎は上下へ振動しながら上流へ伝播していく。そ こで、火炎が上流側へ逆火していく時間帯と下流側へ後退 する時間帯に着目して、ステレオ PIV 計測の結果を示すこ とにする。Fig.6(a) と (b) は条件 A に扔いて、Fig.7(a) と (b) は条件 Bにおいて、逆火した時間帯と後退した時間帯にお ける結果を時系列に沿って並べている。これらの図では、 ガラス管軸方向流速 $v$ と紙面垂直方向流速 $w$ について $6 \mathrm{~ms}$ 毎の瞬時場 2 枚を上下 1 組にして 9 組示した。各図におけ る $t$ は任意の時刻からの時間経過である。各組上側のガラ 又管軸方向流速 $v$ は、上 (下流) 方向を正とし、下（上流） 方向を負として表している。一方、各組下側の紙面垂直方 向流速 $w$ は、紙面手前方向を正とし、紙面奥方向を負とし て示している。さらに、本実験で適応した計測方法では、 燃焼場に打いて火炎も捉えることができるため、火炎は図 中央に存在する黒色の領域にて表す。

まず初めに、Fig.6 と Fig.7 で紙面垂直方向流速 $w$ の全体 的な比較によって、条件 A と B に扔ける相違点を述べる。 Fig.6では全体を通して、旋回流の渦心（紙面垂直方向流 速 $w$ がほぼ 0 の部分）がガラス管中心軸に沿って安定的に 

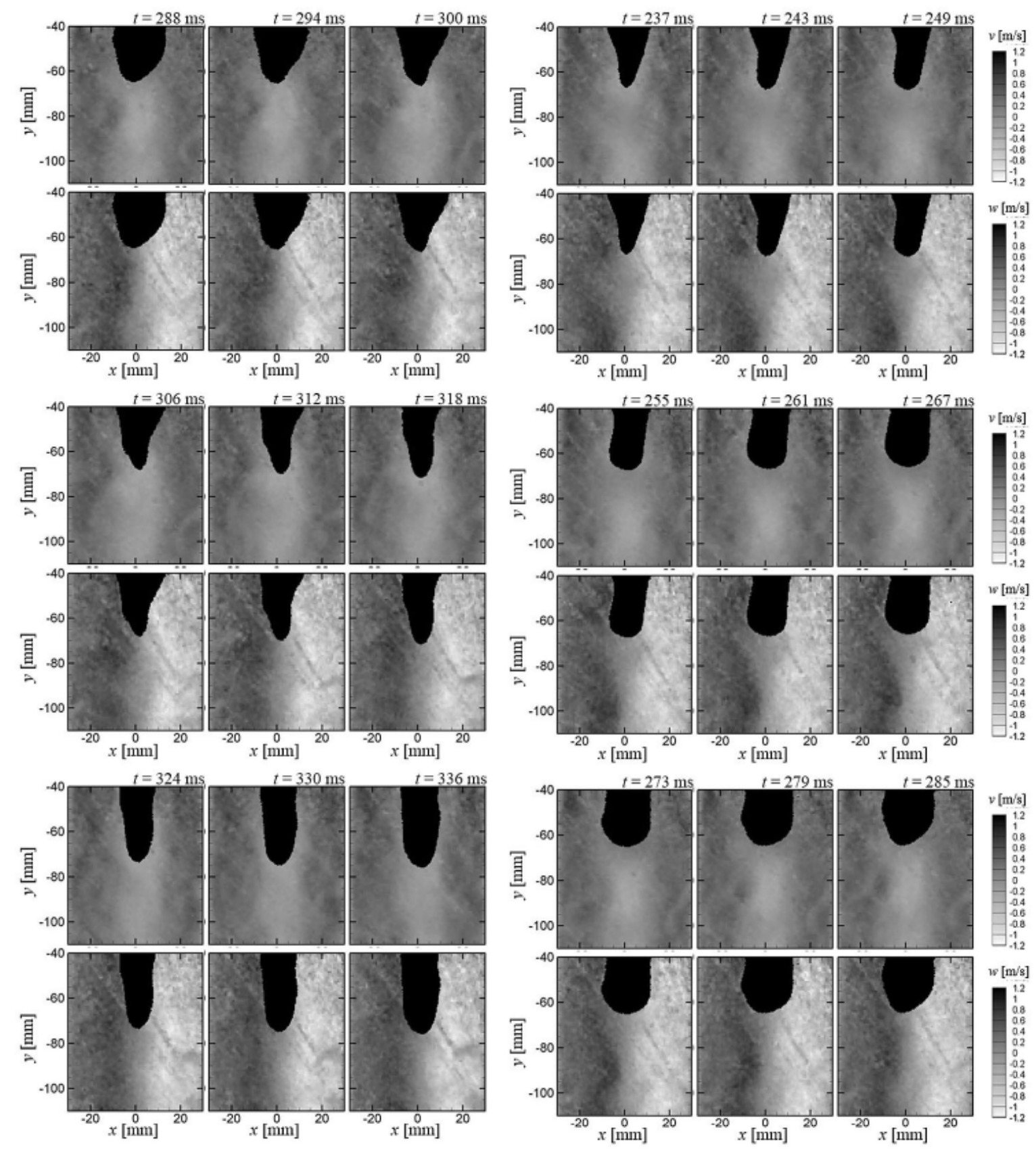

(a) Flashback

(b) Moving back

Fig.6 Time-series axial/circumferential flow field and flame propagation behavior in condition A.

形成されていることが分かる。一方、Fig.7では渦心が湾 曲している瞬時場が多く見られる。つまり、条件 A では渦 心の歳差運動が顕著ではない一方、条件 B では歳差運動が 激しくその半径が大きいと言える。これは、条件 A では旋 回強さが強いため旋回流の渦構造が安定的であり、条件 $\mathrm{B}$ では旋回強さが弱いため渦構造が不安定であることが原因 として考えられる。

次に、各条件において逆火時と後退時それぞれに着目し
て考察する。まず、条件 A において逆火する際の火炎伝播 挙動とガラス管軸方向流速 $v$ または紙面垂直方向流速 $w$ の 相互関係について、Fig.6(a) を用いて述べる。軸方向流速 $v$ に注目すると、 $t=288$ から $294 \mathrm{~ms}$ にかけて逆流している領 域が徐々に火炎に近づいている様子が分かる。そして、 $t=$ $300 \mathrm{~ms}$ 以降、逆流領域と火炎が衝突すると、火炎先端が尖 り、火炎は上流側へと伝播して行くことが分かる。その間 の紙面垂直方向流速 $w$ の分布については、上述した渦心の 

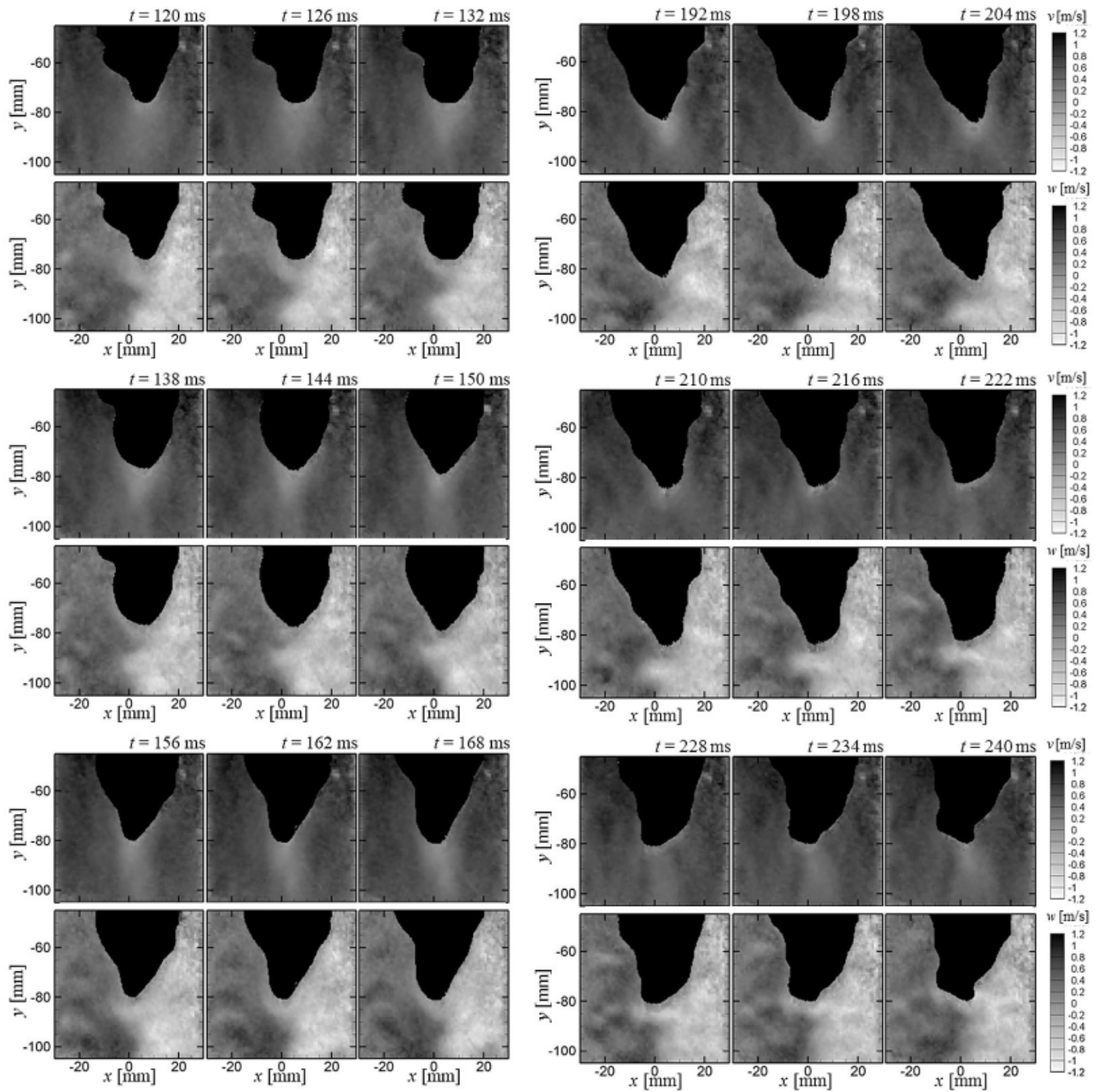

(a) Flashback

(b) Moving back

Fig.7 Time-series axial/circumferential flow field and flame propagation behavior in condition B.

ガラス管半径方向の幅は、火炎幅に比べて十分細く、火炎 先端から上流側まで一様である。このことは、火炎先端上 流側で、旋回流が安定的に形成され、旋回流の強さも他の 時間帯に比べて、比較的強かったことを意味している。つ まり、一時的に旋回流の強さが強まった結果、旋回流の中 心は負圧となり、上流への流れが加速され、その結果、火 炎が上流側へと伝播したことが言える。

また、Fig.6(b) が示す後退時においては、火炎伝播挙動
とガラス管軸方向流速 $\mathrm{v}$ または紙面垂直方向流速 $\mathrm{w}$ の相互 関係に関して、以下のことが言える。この条件 A では、旋 回流による再循環流れによってガラス管中心軸付近におい ては、主に上流への逆流状態となっている。しかし、 $t=$ $237 \mathrm{~ms}$ における軸方向流速 $v$ の瞬時場において、 $y=-80$ $\mathrm{mm}$ 付近でガラス管中心軸でも、下流への流れが分布して いることが分かる。この下流方向への流れをもつ流体塊は その後、火炎先端に近づき、 $t=255 \mathrm{~ms}$ では両者が衝突して 
いる。この瞬間、火炎先端の形状は下に凸から平坦に変わ り、その後火炎が下流側へと押し戻されている様子が分か る。この火炎が後退していく間の紙面垂直方向流速 $w$ との 相互関係については、以下のことが明らかとなった。特に、 火炎が後退する初期の時間帯である $t=255 \mathrm{~ms}$ から $267 \mathrm{~ms}$ においては、火炎先端付近で旋回流の渦心が、ガラス管半 径方向に広がっている。また、この渦心が広がった領域は、 軸方向流速 vの分布において、下流への流れとなっている 箇所と一致する。このことから、火炎先端において局所的 に旋回流の旋回強さが弱まり、旋回流の中心でも下流への 流れが発生し、その流れに乗って火炎は下流側へと後退し たと言える。

それでは、旋回強さが弱かった条件 Bにおいても、逆火 時と後退時における火炎伝播挙動とガラス管軸方向流速 $v$ または紙面垂直方向流速 $w$ の相互関係について示す。逆火 時における軸方向流速と火炎挙動の関係は、Fig.7(a) が示 すように、火炎先端周りだけ極局所的に低速流れが存在し ていることが分かる。この時の紙面垂直方向流速の分布を 見ると、湾曲している旋回流の渦心に関して、その曲率が 後述する後退時と比べて小さいことが分かる。

一方、Fig.7(b) が示す後退時に関しては、特に後退が顕 著であった $t=216$ から $228 \mathrm{~ms}$ では、それ以前には存在し ていた火炎先端付近における流速 0 付近の低速領域がほぼ なくなっていることが分かる。また、紙面垂直方向流速に ついては、 $t=216 \mathrm{~ms}$ 以降、旋回流の渦心が大きく湾曲して おり、その曲率は大きくなっていることが分かる。つまり、 条件 B のような旋回強さが弱い流れ場では、動きの大きい 歳差運動によって、火炎先端付近の渦構造が变化し、軸方 向流速が影響されることによって、火炎の伝播挙動も決定 されることが分かった。

ここで、火炎伝播挙動と流れ場の相互関係を定量的に示 すため、火炎伝播速度とガラス管軸方向速度 $v$ または紙面 垂直方向速度 $w$ の関係を明らかにする。Fig.6 と 7 で示し た $6 \mathrm{~ms}$ 毎の瞬時場のうち任意の一枚において $\left(t=t_{0}\right.$ とする $)$ 火炎先端位置を求め、これと次の $6 \mathrm{~ms}$ 後 $\left(t=t_{0}+6\right)$ の火 炎先端位置との移動距離から求めたものを $t=t_{0}$ における火 炎伝播速度 $v_{\text {flame }}$ と定義し、下流方向へ後退する速度を正、 上流方向へ逆火する速度を負とした。そして、 $t=t_{0}$ におけ る火炎先端付近での未燃予混合気に関するガラス管軸方向 速度 $v$ と紙面垂直方向速度 $w$ を横軸に、火炎伝播速度 $v_{\text {flame }}$ を縦軸に取り、両者の相互関係を考察する。Fig.8 と 9 は、 それぞれ条件 $\mathrm{A}\left(Q_{\text {air }}=50 \mathrm{NL} / \mathrm{min}\right.$ かつ $\left.S=0.633\right)$ と条件B $\left(Q_{\text {air }}\right.$

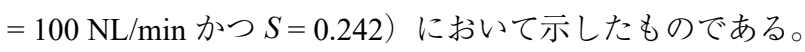

まず、条件 A の結果を表した Fig.8では、軸方向速度と 火炎伝播速度には比例関係が見られ、值自体も近いことが 分かる。つまり、旋回流の強い条件では、火炎先端付近に おける未燃予混合気の軸方向への速度が火炎先端の伝播速 度に影響を与えると言える。その上、火炎の燃焼速度に比

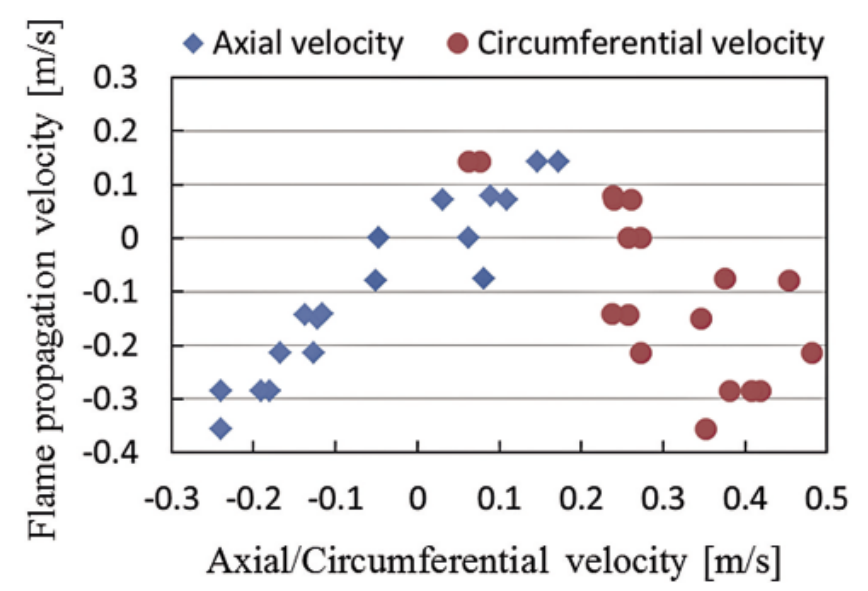

Fig.8 Axial/circumferential velocity and flame propagation velocity in condition A.

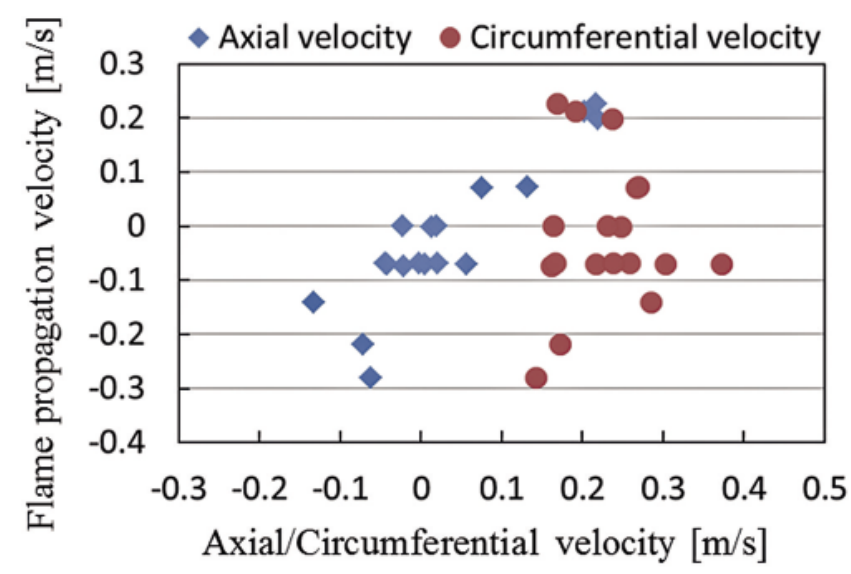

Fig.9 Axial/circumferential velocity and flame propagation velocity in condition B.

べて、火炎先端付近に存在する未燃予混合気の軸方向流速 が十分に大きいため、火炎伝播速度と軸方向流速は近い值 となったと考えられる。次に、火炎先端付近における未燃 予混合気の周方向速度の影響について以下に述べる。Fig.8 が示すように、周方向速度が大きくなるにしたがって、火 炎伝播速度は負の值となっていくことが分かる。つまり、 局所的な旋回強さが強くなると、火炎は逆火することを示 している。よって、火炎先端付近に存在する未燃予混合気 の軸方向速度と周方向速度は共に、火炎伝播速度に影響を 与えることが明らかとなった。これは、火炎先端付近にお いて、旋回流の一時的な旋回強さの強弱に伴って、旋回流 の中心軸上では、旋回流による負圧の大きさが変化し、軸 方向流速が影響を受け、それに伴って火炎伝播速度が変化 したためと言える。

一方、旋回強さの弱い条件 B の結果を示した Fig.9につ いて述べる。この条件においても高旋回場条件 A と同様に、 
火炎伝播速度と火炎先端付近における未燃予混合気の軸方 向速度は比例関係にあることが分かる。つまり、旋回流の 弱い条件でも火炎先端付近に存在する未然予混合気の軸方 向速度が、火炎伝播速度に影響を与えていると言える。次 に、この条件における火炎先端付近に存在する未燃予混合 気に関して、その周方向速度による火炎伝播速度への影響 の有無について述べる。Fig.9 が示すように、ある一定の 周方向速度に対して、火炎伝播速度は不規則な值を取って おり、周方向速度と火炎伝播速度には関係性がないことが 分かる。よって、旋回流の旋回強さが弱い場合は、軸方向 速度と火炎伝播速度には比例関係があるものの、旋回強さ が強い場合とは異なって、周方向速度と火炎伝播速度に顕 著な関係性はないことが明らかとなった。これは、旋回強 さが弱い条件では、渦心の歳差運動によって火炎先端付近 の渦構造が絶えず変化しているため、周方向速度よりも渦 構造の変化が火炎挙動に影響を与えているためと考えられ る。

\section{4. 結 論}

本研究では、ガスタービン燃焼器の一部を模擬した実験 用燃焼器に対して時系列ステレオ PIV 計測を適応し、燃焼 器内に発生させる旋回流の旋回強さの異なる場において、 予混合火炎の伝播挙動と流れ場の相互関係について以下の 知見を明らかにした。

1) 旋回強さが強い条件では、火炎先端付近に存在する未燃 予混合気の燃焼器中心軸方向の速度は、火炎伝播速度に 影響を与え両者は近い值となる。また、火炎先端付近の 予混合気の周方向速度が速くなると、軸方向速度に関し ては上流方向への流れが強くなり逆火に繋がる。つまり、
周方向速度も火炎伝播速度に影響を与える。

2) 旋回強さが弱い条件では、旋回強さが強い場合と同様に、 燃焼器中心軸方向の速度は火炎伝播速度に影響を与え る。しかし、火炎伝播速度は予混合気の周方向速度には 影響を受けず、火炎先端付近の渦構造の変化に影響を受 ける。

\section{参考文献}

1) V. Kurdyumov, E. F. Tarrazo, J. -M. Truffaut, J. Quinard, A. Wangher and G. Searby: Proceedings of the Combustion Institute, 31 (2007) 1275-1282.

2) M. Kröner, J. Fritz and T. Sattelmayer: Proceedings of ASME TURBO EXPO 2002 (2002) Paper No.GT2002-30075.

3) S. Ishizuka: Progress in Energy and Combustion Science, 28-6 (2002) 477-542.

4) N. Syred: Progress in Energy and Combustion Science, 32-2 (2006) 93-161.

5) M. Konle, F. Kiesewetter and T. Sattelmayer: Experiments in Fluids, 44 (2008) 529-538.

6) M. Stöhr, R. Sadanandan and W. Meier: Proceedings of the Combustion Institute, 32 (2009) 2925-2932.

7) T. Owaki and A. Umemura: Proceedings of the Combustion Institute, 31 (2007) 1067-1074.

8) Y. Huang and V. Yang: Proceedings of the Combustion Institute, $\mathbf{3 0}$ (2005) 1775-1782.

9) 市川雄一、小宮山正治、小山敦史：日本機械学会論文集、81827 (2015) 14-00624.

10) M. R. Johnson, D. Littlejohn, W. A. Nazeer, K. O. Smith and R. K. Cheng: Proceedings of the Combustion Institute, 30 (2005) $2867-$ 2874. 